Article

\title{
Synthesis and Structural Characterization of a Silver(I) Pyrazolato Coordination Polymer ${ }^{\dagger}$
}

\author{
Kiyoshi Fujisawa ${ }^{1, * \mathbb{D}}$, Takuya Nemoto ${ }^{1}$, Yui Morishima ${ }^{1}$ and Daniel B. Leznoff ${ }^{2, *}$ \\ 1 Department of Chemistry, Ibaraki University, Mito, Ibaraki 310-8512, Japan; cu_peroxo@yahoo.co.jp (T.N.); \\ fujisawa0608@gmail.com (Y.M.) \\ 2 Department of Chemistry, Simon Fraser University, 8888 University Drive, Burnaby, BC V5A1S6, Canada \\ * Correspondence: kiyoshi.fujisawa.sci@vc.ibaraki.ac.jp (K.F.); dleznoff@sfu.ca (D.B.L.); \\ Tel.: +81-29-853-8373 (K.F.); +1-778-782-4887 (D.B.L.) \\ + Dedication: Dedicated to Professor Edward R.T. Tiekink on the occasion of his 60th birthday.
}

Citation: Fujisawa, K.; Nemoto, T.; Morishima, Y.; Leznoff, D.B. Synthesis and Structural Characterization of a Silver(I) Pyrazolato Coordination Polymer. Molecules 2021, 26, 1015. https://doi.org/10.3390/ molecules 26041015

Academic Editors: Vera L. M. Silva and Artur M. S. Silva

Received: 11 January 2021

Accepted: 12 February 2021

Published: 15 February 2021

Publisher's Note: MDPI stays neutral with regard to jurisdictional claims in published maps and institutional affiliations.

Copyright: (c) 2021 by the authors. Licensee MDPI, Basel, Switzerland. This article is an open access article distributed under the terms and conditions of the Creative Commons Attribution (CC BY) license (https:// creativecommons.org/licenses/by/ $4.0 /)$.

\begin{abstract}
Coinage metal(I) $\cdots$ metal(I) interactions are widely of interest in fields such as supramolecular assembly and unique luminescent properties, etc. Only two types of polynuclear silver(I) pyrazolato complexes have been reported, however, and no detailed spectroscopic characterizations have been reported. An unexpected synthetic method yielded a polynuclear silver(I) complex $[\mathrm{Ag}(\mu-\mathrm{L1Clpz})]_{n}\left(\mathrm{~L} 1 \mathrm{Clpz}^{-}=4\right.$-chloride-3,5-diisopropyl-1-pyrazolate anion) by the reaction of $\left\{[\mathrm{Ag}(\mu-\mathrm{L} 1 \mathrm{Clpz})]_{3}\right\}_{2}$ with $\left({ }^{\mathrm{n}} \mathrm{Bu}_{4} \mathrm{~N}\right)\left[\mathrm{Ag}(\mathrm{CN})_{2}\right]$. The obtained structure was compared with the known hexanuclear silver(I) complex $\left\{[\mathrm{Ag}(\mu-\mathrm{L} 1 \mathrm{Clpz})]_{3}\right\}_{2}$. The Ag $\cdots \mathrm{Ag}$ distances in $[\mathbf{A g}(\mu-\mathbf{L} 1 \mathrm{Clpz})]_{n}$ are slightly shorter than twice Bondi's van der Waals radius, indicating some Ag...Ag argentophilic interactions. Two Ag-N distances in $[\mathbf{A g}(\mu-\mathbf{L 1 C l p z})]_{n}$ were found: $2.0760(13)$ and $2.0716(13) \AA$, and their $\mathrm{N}-\mathrm{Ag}-\mathrm{N}$ bond angles of $180.00(7)^{\circ}$ and $179.83(5)^{\circ}$ indicate that each silver(I) ion is coordinated by two pyrazolyl nitrogen atoms with an almost linear coordination. Every five pyrazoles point in the same direction to form a 1-D zig-zag structure. Some spectroscopic properties of $[\mathrm{Ag}(\mu-\mathrm{LIClpz})]_{n}$ in the solid-state are different from those of $\left\{[\mathrm{Ag}(\mu-\mathrm{L} 1 \mathrm{Clpz})]_{3}\right\}_{2}$ (especially in the absorption and emission spectra), presumably attributable to this zig-zag structure having longer but differently arranged intramolecular Ag...Ag interactions of 3.39171(17) A. This result clearly demonstrates the different physicochemical properties in the solid-state between 1-D coordination polymer and metalacyclic trinuclear (hexanuclear) or tetranuclear silver(I) pyrazolate complexes.
\end{abstract}

Keywords: polynuclear; silver; crystal structure; pyrazolate ligand; coordination polymer

\section{Introduction}

Cyclic trinuclear complexes with monovalent coinage metal ions have been of interest to coordination chemists for three decades [1-3]. One of the ligands known to form these cyclic trinuclear complexes is pyrazolate [4-6], which is known to act as an A-frame-like bridging ligand with some metal ions, with an $\mathrm{Npz}-\mathrm{M}-\mathrm{Npz}$ linear coordination mode ( $\mathrm{pz}=$ pyrazolate anion, $\mathrm{C}_{3} \mathrm{H}_{3} \mathrm{~N}_{2}{ }^{-}$) [1-4,6-9]. Early studies in 1970 suggested that silver(I) pyrazolato complexes existed as a polymeric 1-D chain $[\mathrm{Ag}(\mathrm{pz})]_{n}$ (Figure 1, left) [10]. The structure of $[\mathrm{Ag}(\mathrm{pz})]_{n}$ was discussed in that the deprotonated pyrazolato complexes are "at least trimeric but polymeric forms cannot be excluded", based on far-IR spectroscopy data [11]. The first structural characterization of pyrazolato complexes coordinated by coinage metal(I) ions was determined by Fackler and co-workers in 1988: their reported sil-

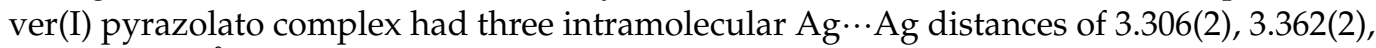
and 3.496(2) $\AA$, forming a trinuclear complex $\left[\mathrm{Ag}\left(3,5-\mathrm{Ph}_{2} \mathrm{pz}\right)_{3}\right]\left(3,5-\mathrm{Ph}_{2} \mathrm{pz}=3,5\right.$-diphenyl1-pyrazolate anion) [12]. After this report, the hexanuclear complex $\left\{\left[\mathrm{Ag}(3,5-\mathrm{Ph} 2 \mathrm{pz})_{3}\right]\right\}_{2}$ was also reported, having one intermolecular Ag...Ag interaction of 2.9712(14) $\AA$ without any crystalline solvents [13]. This dimerization to build the hexanuclear structure can be 
caused by an additional stabilization of the silver(I) ions provided by argentophilic interactions (Ag …Ag interactions) [14]. Subsequent ab initio powder X-ray diffraction (XRD) evidence also indicated two possibilities: silver(I) pyrazolato complexes could exist as either a coordination polymer $[\mathrm{Ag}(\mathrm{pz})]_{n}$ with an intramolecular $\mathrm{Ag} \cdots \mathrm{Ag}$ distance of $3.40 \AA$ or as a dimeric trinuclear $\left\{[\mathrm{Ag}(\mathrm{pz})]_{3}\right\}_{2}$ structure with an intermolecular $\mathrm{Ag} \cdots \mathrm{Ag}$ distance of 3.431(2) $\AA$, depending on the method of synthesis [15]. After that, the single-crystal characterization of the product made by the same synthetic method with aqueous $\mathrm{NH}_{3}$ was reported as $[\mathrm{Ag}(\mathrm{pz})]_{n}$ with an intramolecular $\mathrm{Ag} \cdots \mathrm{Ag}$ (argentophilic) interaction of 3.3718(7) $\AA$, an intermolecular Ag …Ag interaction of 3.2547(6) $\AA$, and an N-Ag-N angle of $169.98^{\circ}$ (14) (Figures S1 and S2) [16]. However, its physicochemical properties such as solid-state photoluminescence have not been reported $[15,16]$.
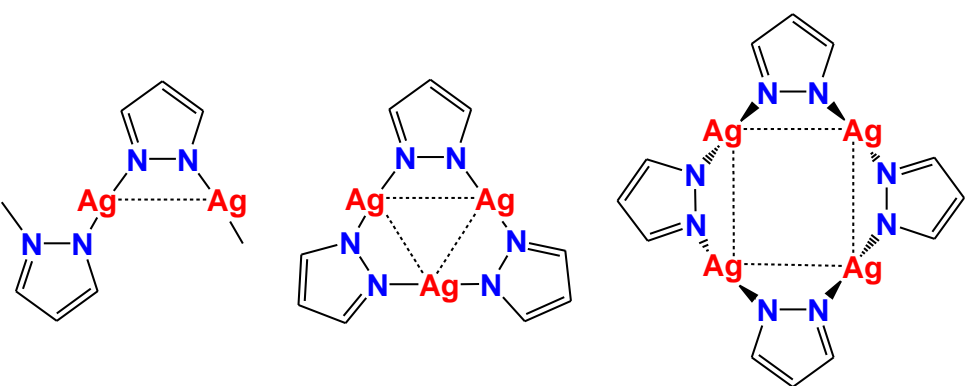

Figure 1. Schematic drawing of silver(I) pyrazolato complexes; left: polynuclear, center: trinuclear, right: tetranuclear. Dotted lines show intramolecular Ag...Ag interactions.

We have previously reported silver(I) pyrazolato complexes synthesized by alkyl- and aryl-substituted pyrazoles to form trinuclear and tetranuclear structures, depending on the method of synthesis and the nature of the substituents on the pyrazolate ring (Figure 1, center and right) [17-22]. Some $\mathrm{Au} \cdots \mathrm{Ag}$ (metallophilic) interactions in cyclic trinuclear coinage metal(I) complexes were found [1,2]. Au-Im complexes can be easily interacted with silver(I) ions to form $\mathrm{Au} \cdots \mathrm{Ag}$ interactions, since the order of $\pi$-acidity is $\mathrm{Au}<\mathrm{Cu}<\mathrm{Ag}$ for a given ligand, and $\mathrm{Im}^{-}$(imidazolate) $<$Pyridine $<\mathrm{Cb}^{-}$(carbeniate) $<\mathrm{Pz}^{-}$for a given metal [1-3]. As an example, the mixed metal(I) complex $\left[\left(\mathrm{Ag}\left\{\left(\left[\mathrm{Au}\left(\mathrm{C}^{2}, N^{3} \text {-bzim }\right)\right]_{3}\right)_{2}\right\}\right]\left(\mathrm{BF}_{4}\right)\right.$ with $\mathrm{Au} \cdots \mathrm{Ag}$ interactions was reported $\left(\mathrm{bzim}^{-}=1\right.$-benzylimidazole anion) [23].

With this electronic preference in mind, to construct Ag $\cdots A$ Ag interactions by silver(I) pyrazolato complexes, it should be valuable to explore the different strategy of using electro-withdrawing substituents on the pyrazole ligand and $\left[\mathrm{Ag}(\mathrm{CN})_{2}\right]^{-}$as a silver(I) ion source. The dicyanoargentate(I) anion is very useful to build coordination polymers [24-28] and performs well as a building block in general [29]. In this article, we report the detailed structure and characterizations as well as the unexpected synthetic procedure that leads to the new polynuclear silver(I) pyrazolato complex $[\mathrm{Ag}(\mu-\mathrm{L} 1 \mathrm{Clpz})]_{n}\left(\mathrm{~L} 1 \mathrm{Clpz}^{-}=4\right.$-chloride3,5-diisopropyl-1-pyrazolate anion) (Figure 2).<smiles>CC(C)c1cc(C(C)C)[nH]n1</smiles>

L1pz-H<smiles>Cc1n[nH]c(C(C)C)c1Cl</smiles>

L1Clpz-H<smiles>CC(C)c1n[nH]c(C(C)C)c1Br</smiles>

L1Brpz-H<smiles>CC(C)c1n[nH]c(C(C)C)c1I</smiles>

L1Ipz-H

Figure 2. Pyrazoles used in this research.

\section{Results and Discussion}

\subsection{Synthesis}

The reaction of $\left\{[\mathrm{Ag}(\mu-\mathrm{L} 1 \mathrm{Clpz})]_{3}\right\}_{2}$ with 1.5 equivalents of $\left({ }^{\mathrm{n}} \mathrm{Bu}_{4} \mathrm{~N}\right)\left[\mathrm{Ag}(\mathrm{CN})_{2}\right]$ in ethyl acetate was carried out at room temperature as shown in Scheme 1. After one week of 
reaction time, a white powder was gradually generated. Its IR spectroscopic measurement revealed that the $v(C \equiv N)$ stretching peak of the starting material $\left({ }^{n} \mathrm{Bu}_{4} \mathrm{~N}\right)\left[\mathrm{Ag}(\mathrm{CN})_{2}\right]$ at $2141 \mathrm{~cm}^{-1}$ disappeared and a new complex that did not contain any cyanide was generated. From a slow liquid-liquid diffusion method, we obtained a few single-crystals to reveal the structure (see Section 2.2). The above white powders prepared in the bulk synthetic method were the same as that obtained in single-crystal form and structurally characterized (below), as confirmed by the comparison of the powder X-ray diffractogram of the powder and the powder pattern generated from the single-crystal structure, as shown in Figure S3. As mentioned in the Introduction, although a $[\mathrm{Ag}(\mu-\mathrm{L} 1 \mathrm{Clpz})]_{3} /\left[\mathrm{Ag}(\mathrm{CN})_{2}\right]^{-}$based polynuclear structure with intermolecular Ag...Ag interactions was initially targeted, only the polynuclear silver(I) complex $[\mathbf{A g}(\mu-\mathbf{L} \mathbf{C l} \mathbf{C l} z)]_{n}$, identified as a coordination polymer was obtained (Scheme 1); the detailed mechanism leading to this product was not explored. This coordination polymer assembly was only successfully performed by $\left\{[\mathrm{Ag}(\mu-\mathrm{L} 1 \mathrm{Clpz})]_{3}\right\}_{2}$ but was not observed either by the non-halogenated derivative $\left\{[\mathrm{Ag}(\mu-\mathrm{L} 1 \mathrm{pz})]_{3}\right\}_{2}$ or the other halogenated derivatives $\left\{[\mathrm{Ag}(\mu-\mathrm{L} 1 \mathrm{Brpz})]_{3}\right\}_{2}$ and $\left\{[\operatorname{Ag}(\mu-\mathrm{L} 1 \mathrm{Ipz})]_{3}\right\}_{2}$ (Figure 2$)$. The reactions of these other hexanuclear complexes with $\left({ }^{n} \mathrm{Bu}_{4} \mathrm{~N}\right)\left[\mathrm{Ag}(\mathrm{CN})_{2}\right]$ did not produce any powder precipitate. Indeed, after all of the solvent had slowly evaporated from the reaction mixture, powder XRD measurements were carried out on the resulting residues, which indicated that no new complexes were generated: only a physical mixture of the initial starting materials, i.e., the hexanuclear complexes $\left\{[\mathrm{Ag}(\mathrm{L} 1 \mathrm{Xpz})]_{3}\right\}_{2}(X=\mathrm{H}, \mathrm{Br}$, and I) and $\left({ }^{n} \mathrm{Bu}_{4} \mathrm{~N}\right)\left[\mathrm{Ag}(\mathrm{CN})_{2}\right]$ were observed. We also tried to make polynuclear $[\mathrm{Ag}(\mu-\mathrm{L} 1 \mathrm{Xpz})]_{n}$ $\left(\mathrm{X}=\mathrm{H}, \mathrm{Cl}, \mathrm{Br}\right.$, and $\mathrm{I}$ ) by the literature method by using aqueous $\mathrm{NH}_{3}[15,16]$, but only the same hexanuclear complexes $\left\{[\mathrm{Ag}(\mathrm{L} 1 \mathrm{Xpz})]_{3}\right\}_{2}(\mathrm{X}=\mathrm{H}, \mathrm{Cl}, \mathrm{Br}$, and I) were obtained.
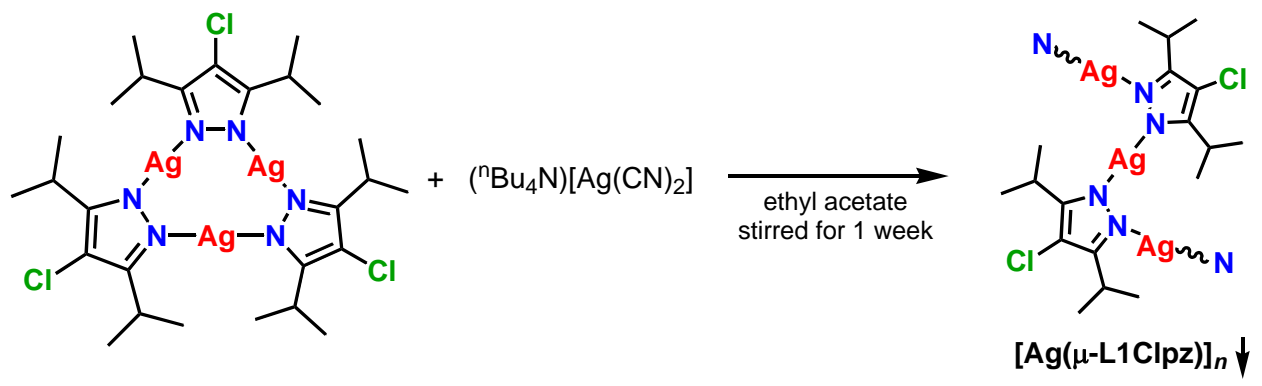

Scheme 1. Synthetic scheme of silver(I) coordination polymer $[\operatorname{Ag}(\mu-\mathrm{L1Clpz})]_{n}$.

\subsection{Structure}

Single-crystal X-ray structural analysis was performed on the polynuclear silver(I) material $[\mathbf{A g}(\mu-\mathbf{L 1 C l p z})]_{n}$, the perspective drawing of which is shown in Figure 3 . The relevant bond lengths $(\AA)$ and angles $\left(^{\circ}\right)$ are noted in the caption. The 1-D coordination polymer $[\mathbf{A g}(\mu-\mathbf{L 1 C l p z})]_{n}$ and packing diagram are drawn in Figure 4 and Figure $S 4$, respectively.

[Ag( $\mu$-L1Clpz $)]_{n}$ exists as a coordination polymer with an intramolecular argentophilic distance of Ag1 ‥Ag2, 3.39171(17) $\AA$, which is slightly shorter than twice Bondi's van der Waals radius $(3.44 \AA=1.72 \AA \times 2)$ [30], indicating the presence of $\mathrm{Ag} \cdots \mathrm{Ag}$ argentophilic interactions [14]. Two Ag-N distances were found: Ag1-N1, 2.0760(13) $\AA$ and Ag2-N2, 2.0716(13) $\AA$. The N-Ag-N bond angles of $180.00(7)^{\circ}\left(\mathrm{N} 1-\mathrm{Ag} 1-\mathrm{N} 1^{\prime}\right)$ and $179.83(5)^{\circ}\left(\mathrm{N} 2^{\prime}-\mathrm{Ag} 2^{\prime}-\mathrm{N} 2^{\prime \prime}\right)$ indicate that each silver(I) ion has two pyrazolyl nitrogen atoms coordinated in an almost linear fashion. Two of the pyrazolate aromatic rings are completely co-planar with a dihedral angle of $0^{\circ}$ (between pyrazole ring 1 and 2), and another pair is twisted relative to each other, with a dihedral angle of $79.24(7)^{\circ}$ (between pyrazole ring 2 and 3) as shown in Figure 3. Every five pyrazole units point in the same direction, thereby forming a 1-D zig-zag structure. Each 1-D zig-zag structure is isolated and there are no significant interactions with the neighboring zig-zag chain. Within each 1-D zig-zag

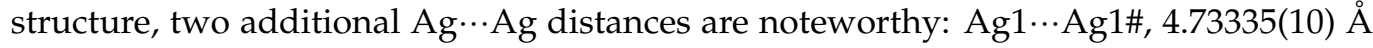


and $\mathrm{Ag} 2 \cdots \mathrm{Ag} 2^{\prime}, 6.7834(3) \AA$. A. Moreover, this zig-zag structure has two Ag-based different angles with $\mathrm{Ag} 2 \cdots \mathrm{Ag} 1 \cdots \mathrm{Ag} 2^{\prime}, 180.000(4)^{\circ}$ and $\mathrm{Ag} 1 \cdots \mathrm{Ag} 2^{\prime} \cdots \mathrm{Ag} 1 \#, 88.499(6)^{\circ}$ (Figure 3).

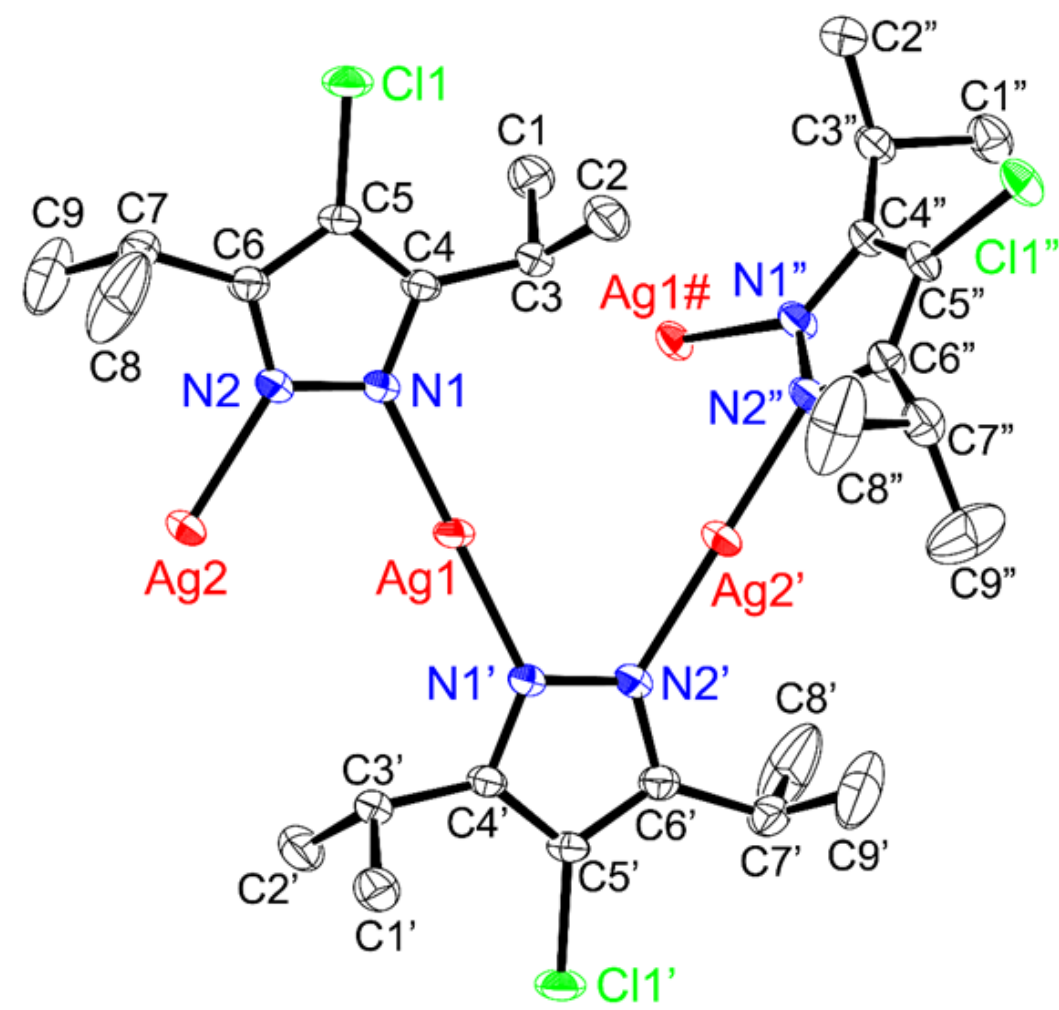

Figure 3. Crystal structure of $[\mathbf{A g}(\mu-\mathrm{L1Clpz})]_{n}$ showing $50 \%$ displacement ellipsoids and the atom labeling scheme. Hydrogen atoms were omitted for clarity. Relevant bond lengths $(\AA)$ and angles $\left.{ }^{\circ}\right)$ : Ag1-N1, 2.0760(13); Ag2-N2, 2.0716(13); Ag1-N1', 2.0760(13); Ag2'-N2', 2.0716(13); Ag2'N2", 2.0716(13); Ag1\#-N1", 2.0760(13); N1-N2, 1.3827(18); N1-Ag1-N1', 180.00(7); N2'-Ag2'-N2",

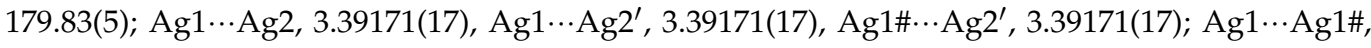

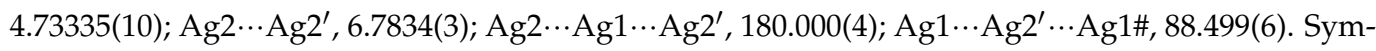
metry codes: ', $-\mathrm{x}+2,-\mathrm{y}+1,-\mathrm{z}+2 ;{ }^{\prime \prime}, \mathrm{x}+1,-\mathrm{y}+1, \mathrm{z} ; \#,-\mathrm{x}+1 / 2+2, \mathrm{y},-\mathrm{z}+2$.
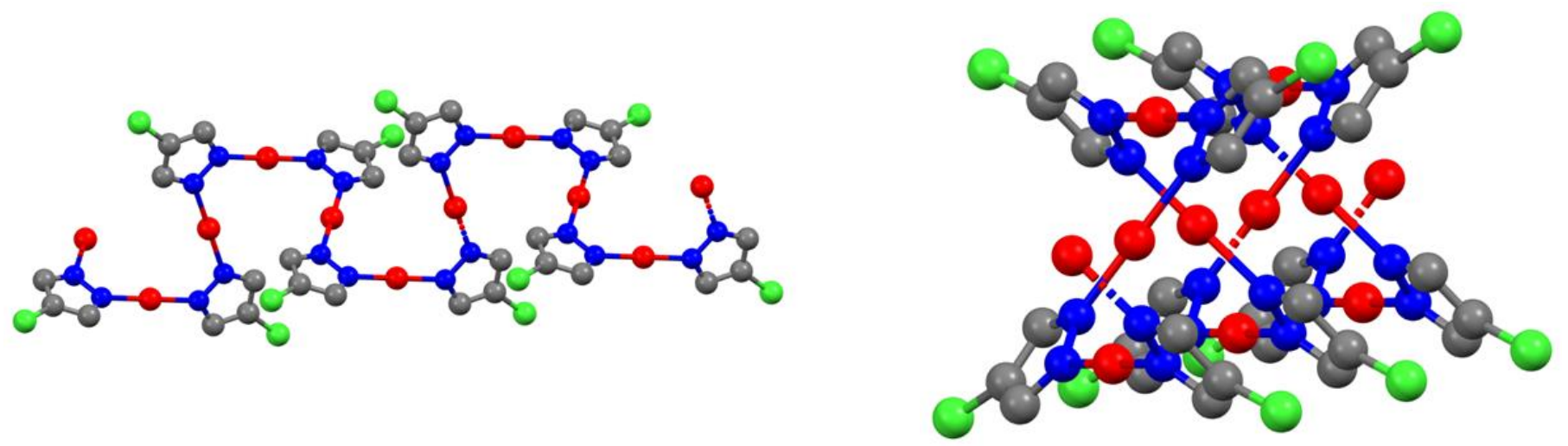

Figure 4. 1-D polynuclear structure of $[\mathrm{Ag}(\mu-\mathrm{L1Clpz})]_{n}(\mathbf{l e f t})$ top view and (right) side view. Carbon atoms of isopropyl group and hydrogen atoms were omitted for clarity. Color: red, silver; blue, nitrogen; green, chlorine; grey, carbon.

This $[\mathrm{Ag}(\mu-\mathrm{L} \mathbf{1 C l p z})]_{n}$ structure is completely different from the reported one for $[\mathrm{Ag}(\mathrm{pz})]_{n}$ which exhibits an intramolecular Ag $\cdots$ Ag distance of 3.3718(7) $\AA$. The zig-zag chain in $[\mathrm{Ag}(\mathrm{pz})]_{n}$ also interacts with neighboring zig-zag chains via inter-chain $\mathrm{Ag} \cdots \mathrm{Ag}$ distances of 3.2547(6) $\AA$ (Figures S1 and S2). The zig-zag structure in [Ag( $\mu$-L1Clpz) $]_{n}$ is 
also different from the original hexanuclear silver(I) complex $\left\{[\mathrm{Ag}(\mu-\mathrm{L} 1 \mathrm{Clpz})]_{3}\right\}_{2}$, which features a dimeric trinuclear structure with three intermolecular argentophilic interactions of 3.1003(17), 3.1298(15), and 3.1051 $\AA$ to form an overall hexanuclear structure (Figures S5 and S6) [20]. These distances are significantly shorter than twice Bondi's van der Waals radius (3.44 $\AA$ ) [30], indicating a strong Ag...Ag argentophilic interaction [14] (Figure S4). The layered structure of $\left\{[\mathrm{Ag}(\mu-\mathrm{L} 1 \mathrm{Clpz})]_{3}\right\}_{2}$ did not interact with the neighboring layered one (Figure S6). The layered structure was formed with longer $\mathrm{Ag} \cdots \mathrm{Ag}$ distances between two $\left\{[\mathrm{Ag}(\mu-\mathrm{L} 1 \mathrm{Clpz})]_{3}\right\}_{2}$ complexes of 7.3531(18), 7.3881(17), and 7.5258(18) ^.

\subsection{Solution-State Properties}

The ${ }^{1} \mathrm{H}-\mathrm{NMR}$ spectrum of the obtained white powder $[\mathbf{A g}(\boldsymbol{\mu}-\mathbf{L} \mathbf{C} \mathbf{C l p z})]_{n}$ in $\mathrm{CDCl}_{3}$ was measured (Figure S7) and the observed chemical shifts are identical to those of $\{[\operatorname{Ag}(\mu-$ L1Clpz) $\left.]_{3}\right\}_{2}$ (Table S1) [20], indicating that the supramolecular solid-state 1-D zig-zag structure of $[\mathrm{Ag}(\mu-\mathrm{L} 1 \mathrm{Clpz})]_{n}$ is not stable upon dissolution, converting to form the known hexanuclear silver(I) complex $\left\{[\mathrm{Ag}(\mu-\mathrm{L} 1 \mathrm{Clpz})]_{3}\right\}_{2}$. This observation is also supported by its solution-state UV-Vis spectrum in cyclohexane (Figure S8) and photoluminescence spectrum in cyclohexane (Figure S9). The maximum peak position in UV-Vis spectrum is $226 \mathrm{~nm}$ which is the same position as that of $\left\{[\mathrm{Ag}(\mu-\mathrm{L} 1 \mathrm{Clpz})]_{3}\right\}_{2}(226 \mathrm{~nm})$ [20]. Moreover, the emissive maximum is $307 \mathrm{~nm}$ ( $280 \mathrm{~nm}$ excitation), which is also the same position as that of $\left\{[\mathrm{Ag}(\mu-\mathrm{L} 1 \mathrm{Clpz})]_{3}\right\}_{2}$. Therefore, detailed comparisons between $[\mathrm{Ag}(\mu-\mathrm{L} \mathbf{C l} \mathbf{p z z})]_{n}$ and $\left\{[\mathrm{Ag}(\mu-\mathrm{L} 1 \mathrm{Clpz})]_{3}\right\}_{2}$ were carried out by solid-state spectroscopies.

\subsection{Solid-State Properties}

IR and Raman spectra of the $[\mathrm{Ag}(\mu-\mathrm{L} 1 \mathrm{Clpz})]_{n}$ and $\left\{[\mathrm{Ag}(\mu-\mathrm{L} 1 \mathrm{Clpz})]_{3}\right\}_{2}$ complexes are reproduced in Figures S10 and S11, respectively. The $\mathrm{C}=\mathrm{N}$ stretching vibrations of 1506 $\mathrm{cm}^{-1}$ (IR) and of 1507 and $1495 \mathrm{~cm}^{-1}$ (Raman) in $[\mathrm{Ag}(\mu-\mathrm{L} 1 \mathrm{Clpz})]_{n}$ are almost the same as the $\mathrm{C}=\mathrm{N}$ stretching vibrations of $1505 \mathrm{~cm}^{-1}$ (IR) and $1495 \mathrm{~cm}^{-1}$ (Raman) in $\{[\mathrm{Ag}(\mu-$ $\left.\mathrm{L} 1 \mathrm{Clpz})]_{3}\right\}_{2}$. The $\mathrm{C}-\mathrm{Cl}$ stretching vibrations could be observed in the far-IR region of $587 \mathrm{~cm}^{-1}$ (IR) and $575 \mathrm{~cm}^{-1}$ (Raman) in $[\mathbf{A g}(\mu-\mathrm{L} \mathbf{C l} \mathbf{C l p z})]_{n}$, which are slightly shifted from $579 \mathrm{~cm}^{-1}$ (IR) and $573 \mathrm{~cm}^{-1}$ (Raman) in $\left\{[\mathrm{Ag}(\mu-\mathrm{L} 1 \mathrm{Clpz})]_{3}\right\}_{2}$ [20], respectively. The $\mathrm{Ag}-\mathrm{N}$ stretching vibration should be observed at around $510 \mathrm{~cm}^{-1}[20,21,31]$ and was observed at $511 \mathrm{~cm}^{-1}$ (Raman) in $[\mathbf{A g}(\mu-\mathrm{L} 1 \mathrm{Clpz})]_{n}$, which was the same energy at $511 \mathrm{~cm}^{-1}$ (Raman) in $\left\{[\mathrm{Ag}(\mu-\mathrm{L} 1 \mathrm{Clpz})]_{3}\right\}_{2}$ [20]. These vibrational spectroscopy comparisons indicate that each stretching vibration energy is almost the same as the other, although there is a clearly measurable difference in the $\mathrm{C}-\mathrm{Cl}$ stretches, consistent with the presence of intercluster $\mathrm{Cl} \cdots \mathrm{Cl}$ interactions in the hexanuclear system $(3.852 \AA)$ that are absent in the 1-D zig-zag chain structure.

The solid-state UV-Vis absorption spectrum of $[\mathrm{Ag}(\mu-\mathrm{L} 1 \mathrm{Clpz})]_{n}$ acquired as a Nujol suspension is shown in Figure 5, along with that of $\left\{[\mathrm{Ag}(\mu-\mathrm{L} 1 \mathrm{Clpz})]_{3}\right\}_{2}[20]$ for comparison. The characteristic absorption band at $225 \mathrm{~nm}$ in $\left\{[\mathrm{Ag}(\mu-\mathrm{L} 1 \mathrm{Clpz})]_{3}\right\}_{2}$ [20] was obviously shifted to lower energy at $248 \mathrm{~nm}$ with a shoulder peak around $280 \mathrm{~nm}$ for the 1-D zig-zag structure. This is clearly different from the behavior of solution-state UV-Vis absorption spectra as shown in Figure S8. This shift in $[\mathbf{A g}(\mu-\mathrm{L} 1 \mathrm{Clpz})]_{n}$ may be caused by polynuclear formation with intramolecular argentophilic interactions of Ag1 ‥Ag2, 3.39171(17) $\AA$ as shown in Figure 3. For this detailed assignment, density functional theory calculations are required but are beyond the scope of this article. Nevertheless, the absorption band can be assigned to a silver(I) to pyrazolate change transfer (MLCT) based on the other reported hexanuclear coinage metal(I) complexes [18-20,32]. 


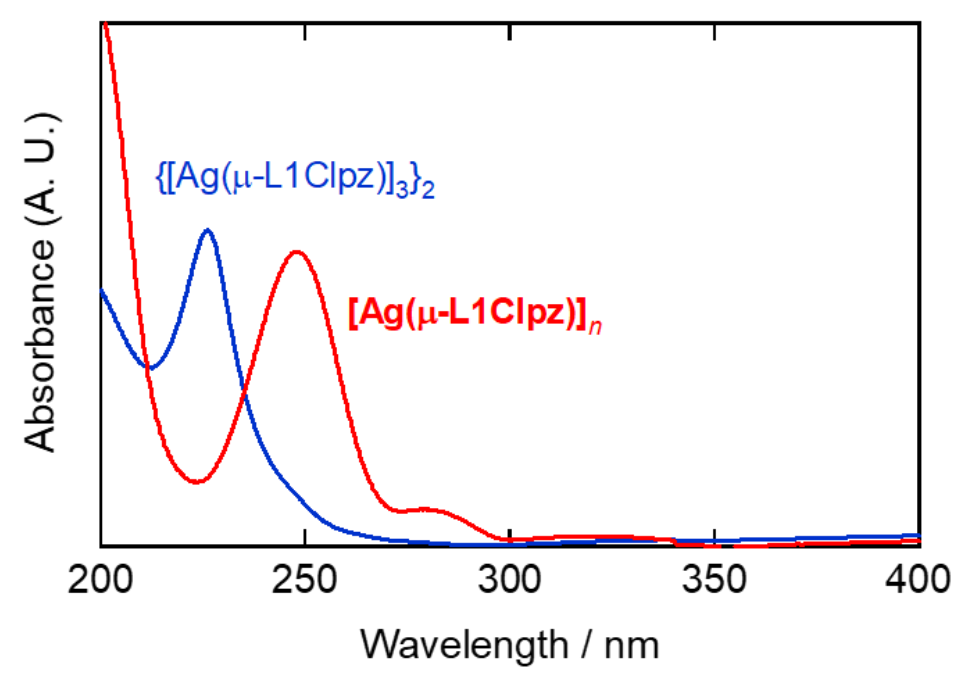

Figure 5. Solid-state UV-Vis absorption spectra of $[\mathrm{Ag}(\boldsymbol{\mu}-\mathbf{L} 1 \mathrm{Clpz})]_{\boldsymbol{n}}$ (red line) and $\left\{[\mathrm{Ag}(\mu-\mathrm{L} 1 \mathrm{Clpz})]_{3}\right\}_{2}$ (blue line) [20] recorded in a Nujol mull.

The emission spectrum of $[\mathbf{A g}(\boldsymbol{\mu}-\mathbf{L 1 C l p z})]_{n}$ in the solid-state was also somewhat different from that of the hexanuclear silver(I) analogue $\left\{[\mathrm{Ag}(\mu-\mathrm{L} 1 \mathrm{Clpz})]_{3}\right\}_{2}$ [20] as shown in Figure 6 at room temperature, recorded using a $280 \mathrm{~nm}$ excitation wavelength. In $\left\{[\mathrm{Ag}(\mu-\mathrm{L} 1 \mathrm{Clpz})]_{3}\right\}_{2}$, the main emissive band at $374 \mathrm{~nm}$ and an additional small one at 312 $\mathrm{nm}$ were observed. However, the emission of the coordination polymer $[\mathbf{A g}(\mu-\mathbf{L 1 C l p z})]_{n}$ was clearly shifted to higher energy around $314 \mathrm{~nm}$, and a new broad peak around $490 \mathrm{~nm}$ was observed.

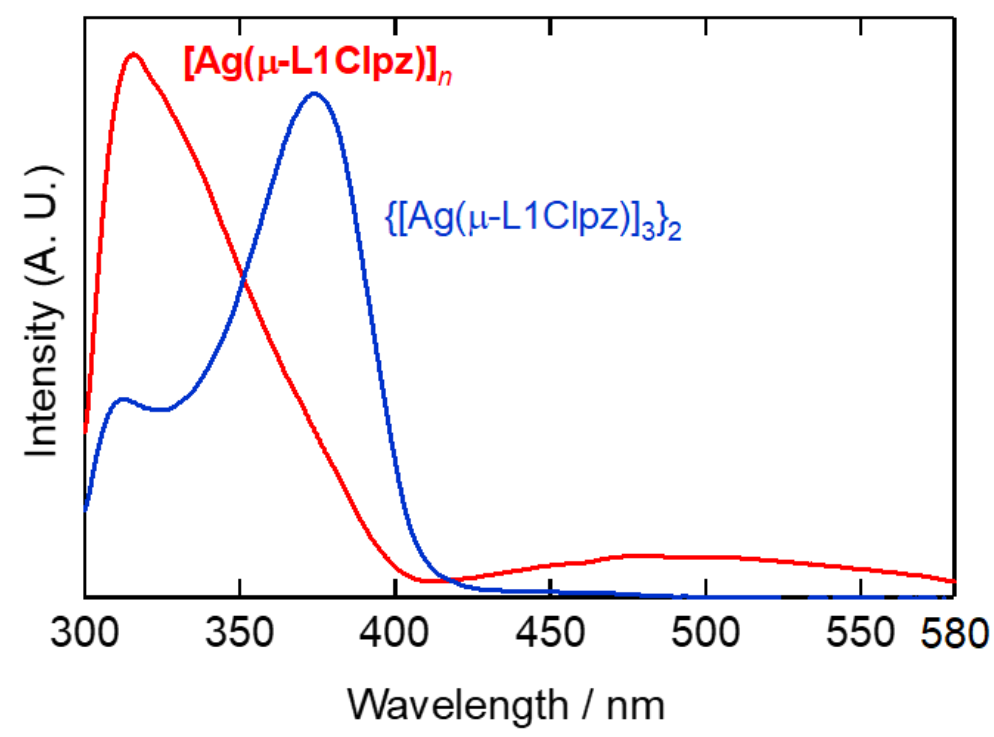

Figure 6. Solid-state photoluminescence spectra of $[\mathrm{Ag}(\mu-\mathrm{L1Clpz})]_{n}$ (red line) and $\left\{[\mathrm{Ag}(\mu-\mathrm{L} 1 \mathrm{Clpz})]_{3}\right\}_{2}$ (blue line) [20] at room temperature recorded at $280 \mathrm{~nm}$ excitation wavelength.

The temperature-dependent photoluminescence spectra in $[\mathbf{A g}(\mu-\mathbf{L 1 C l p z})]_{n}$ were recorded (Figure 7). The corresponding variable temperature emission spectra for $\{[\mathrm{Ag}(\mu-$ L1Clpz) $\left.]_{3}\right\}_{2}$ are also shown in Figure S12 [20]. The more intense $473 \mathrm{~nm}$ emission band of $[\mathbf{A g}(\mu-\mathbf{L 1 C l p z})]_{n}$ at $83 \mathrm{~K}$ exhibited an additional vibrational fine structure around $346 \mathrm{~nm}$, which was observed only at $83 \mathrm{~K}$. From this vibrational behavior, this higher energy emission may be from ligand-based phosphorescence. On the other hand, the lower energy emission band was attributed to metal-based phosphorescence arising from closed shell $\mathrm{d}^{10}-\mathrm{d}^{10}$ intramolecular Ag...Ag interactions [18-21,32-34]. For the original hexanuclear complex $\left\{[\mathrm{Ag}(\mu-\mathrm{L} 1 \mathrm{Clpz})]_{3}\right\}_{2}$, the intensity of both bands at 374 and $312 \mathrm{~nm}$ gradually increased as 
the measurement temperature decreased. No bands around $470 \mathrm{~nm}$ were observed, even at low temperature. From these observations, the lower energy strong emission band at $473 \mathrm{~nm}$ in $[\mathbf{A g}(\mu-\mathbf{L} \mathbf{C l} \mathbf{l p z})]_{n}$ is very unique due to its polynuclear supramolecular structure. We are now in the process of probing the origin of this stimulating behavior by theoretical and more detailed physicochemical researches.

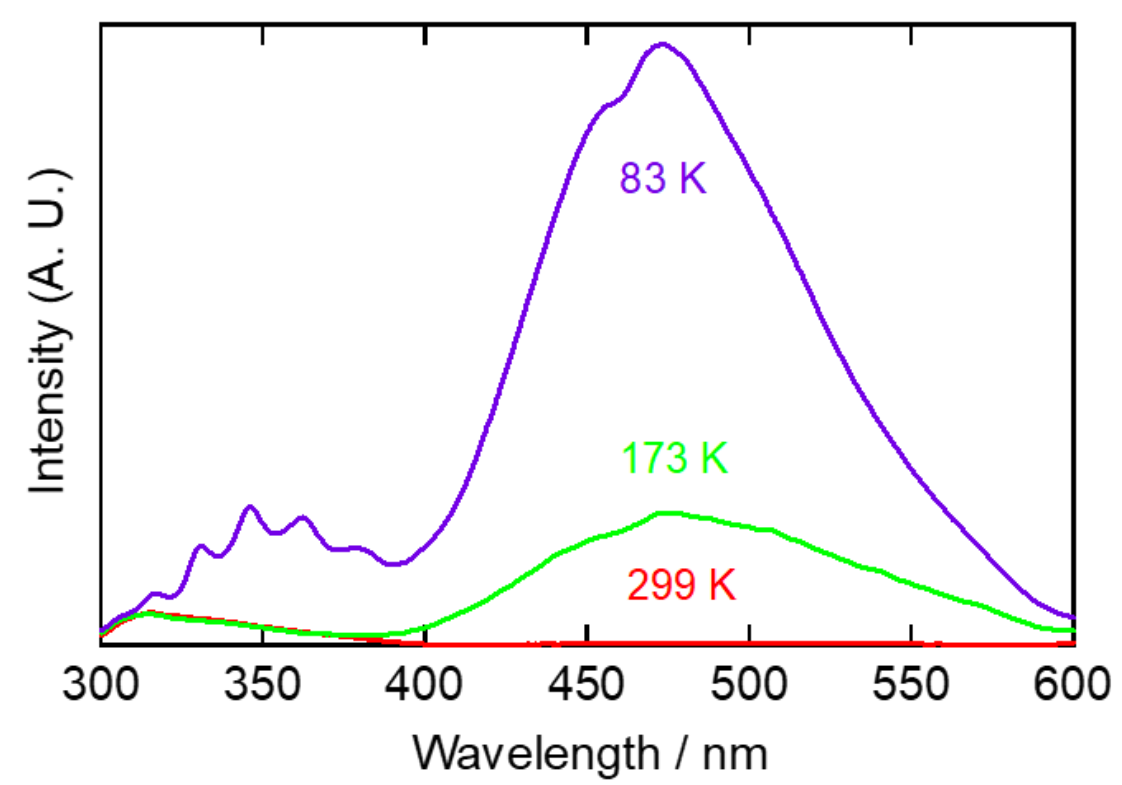

Figure 7. Solid-state temperature-dependent photoluminescence spectra at $83 \mathrm{~K}$ (violet line), $173 \mathrm{~K}$ (green line), and $299 \mathrm{~K}$ (red line) in $[\mathbf{A g}(\mu-\mathbf{L} 1 \mathrm{Clpz})]_{n}$ at $280 \mathrm{~nm}$ excitation.

\section{Materials and Methods}

\subsection{Material and General Techniques}

The preparation and handling of all complexes was performed under an argon atmosphere using standard Schlenk tube techniques. Ultra-dry ethyl acetate was purchased from Wako Pure Chemical Ind. Ltd. and deoxygenated by purging with argon gas. Deuteriochloroform was obtained from Cambridge Isotope Laboratories, Inc. Other reagents were commercially available and were used without further purification. The 3,5-diisopropyl-1pyrazole (L1pz-H) [35] and its halogenated pyrazoles (L1Clpz-H, L1Brpz-H, and L1Ipz$\mathrm{H})$ [20] were prepared by published methods. $\left({ }^{n} \mathrm{Bu}_{4} \mathrm{~N}\right)\left[\mathrm{Ag}(\mathrm{CN})_{2}\right]$ was obtained by the reaction of $\mathrm{KAg}(\mathrm{CN})_{2}(1.016 \mathrm{~g}, 5.10 \mathrm{mmol})$ and ${ }^{\mathrm{n}} \mathrm{Bu}_{4} \mathrm{NBr}(1.7029 \mathrm{~g}, 5.28 \mathrm{mmol})$ in $20 \mathrm{~mL}$ of $\mathrm{H}_{2} \mathrm{O}$ at room temperature for 2 hours to form a white powder of $\left({ }^{\mathrm{n}} \mathrm{Bu}_{4} \mathrm{~N}\right)\left[\mathrm{Ag}(\mathrm{CN})_{2}\right]$ (1.801 g, $4.48 \mathrm{mmol}, 88 \%$ yield). Hexanuclear silver(I) complexes (\{[Ag( $\mu$-L1Clpz $\left.]_{3}\right\}_{2}$, $\left\{[\mathrm{Ag}(\mu-\mathrm{L} 1 \mathrm{Brpz})]_{3}\right\}_{2}$, and $\left.\left\{[\mathrm{Ag}(\mu-\mathrm{L} 1 \mathrm{Ipz})]_{3}\right\}_{2}\right)$ were obtained by the published methods [20].

\subsection{Instrumentation}

IR spectra (4000-400 $\left.\mathrm{cm}^{-1}\right)$ and far-IR spectra $\left(680-150 \mathrm{~cm}^{-1}\right)$ were recorded as $\mathrm{KBr}$ pellets using a JASCO FT/IR-6300 spectrophotometer and as CsI pellets using a JASCO FT/IR 6700 spectrophotometer (JASCO, Tokyo, Japan), respectively. Raman spectra (4000-200 $\mathrm{cm}^{-1}$ ) were measured as powders on a JASCO RFT600 spectrophotometer with a YAG laser $600 \mathrm{~mW}$ (JASCO, Tokyo, Japan). Abbreviations used in the description of vibration data are as follows: s, strong; m, medium; w, weak. ${ }^{1} \mathrm{H}-\mathrm{NMR}(500 \mathrm{MHz})$ spectra were obtained on a Bruker AVANCE III-500 NMR spectrometer at room temperature (298 K) in $\mathrm{CDCl}_{3}$ (Bruker, Yokohama, Japan). ${ }^{1} \mathrm{H}$ chemical shifts were reported as $\delta$ values relative to residual solvent peaks. UV-Vis spectra (solution and solid, 800-200 nm) were recorded on a JASCO V-570 spectrophotometer (JASCO, Tokyo, Japan). The values of $\varepsilon$ were calculated per metal(I) ion. Solid samples (mulls) for spectroscopy were prepared by finely grinding microcrystalline material into powders with a mortar and pestle and then adding mulling agents (Nujol, poly(dimethylsiloxane), viscosity 10,000 (Aldrich)) before uniformly 
spreading it between quartz plates. Powder X-ray diffraction (XRD) measurements were conducted on a Rigaku SmartLab-SP/IUA X-ray diffractometer (Rigaku, Tokyo, Japan) with a Cu K $\alpha$ radiation $(\lambda=1.54 \AA)$ source $(40 \mathrm{kV}, 30 \mathrm{~mA})$ and a high-speed one-dimensional detector D/teX Ultra 250 . The $2 \theta$ was measured in the range of $5-90^{\circ}$ with a scan step of $0.02^{\circ}$ and scan speed of $10^{\circ} \mathrm{min}^{-1}$. Solid samples for XRD were prepared by finely grinding microcrystalline materials into powders with a mortar and pestle and then placing them on an aluminum dish (0.2 $\mathrm{mm}$ thickness). Luminescence spectra were recorded on a JASCO FP-6500 (solid, 700-300 nm) spectrofluorometer (JASCO, Tokyo, Japan). Low-temperature electronic absorption and luminescence spectra were recorded using solid samples cooled with a liquid nitrogen cryostat (CoolSpeK USP-203) from Unisoku Scientific Instruments (Osaka, Japan). The elemental analyses (C, H, and N) were performed by the Chemical Analysis Center of Ibaraki University.

\subsection{Preparation of Complexes \\ $[\mathrm{Ag}(\mu-\mathrm{L} 1 \mathrm{Clpz})]_{\mathbf{n}}$}

$\left\{[\mathrm{Ag}(\mu-\mathrm{L} 1 \mathrm{Clpz})]_{3}\right\}_{2}(54.5 \mathrm{mg}, 0.0309 \mathrm{mmol})$ and $\left({ }^{\mathrm{n}} \mathrm{Bu} 4 \mathrm{~N}\right)\left[\mathrm{Ag}(\mathrm{CN})_{2}\right](19.1 \mathrm{mg}, 0.0475 \mathrm{mmol})$ were dissolved in ethyl acetate $\left(6 \mathrm{~cm}^{3}\right)$ and the solution was stirred at room temperature for one week. A white solid was precipitated during this time. After this, the white solid was filtered and washed with a small amount of ethyl acetate. The obtained white powder as $[\mathbf{A g}(\mu-\mathbf{L} 1 \mathrm{Clpz})]_{n}$ was dried by vacuum pump.

Yield: $22.7 \mathrm{mg}, 0.077 \mathrm{mmol}, 42 \%$.

Calcd for $\mathrm{C}_{9} \mathrm{H}_{14} \mathrm{AgClN}{ }_{2} \cdot 1 / 4\left(\mathrm{H}_{2} \mathrm{O}\right)$ : C, 36.27; $\mathrm{H}, 4.90 ; \mathrm{N}, 9.40$. Found: $\mathrm{C}, 36.21 ; \mathrm{H}, 4.57$; $\mathrm{N}$, 9.20. IR $\left(\mathrm{KBr}, \mathrm{cm}^{-1}\right): 2971 \mathrm{~s}(\mathrm{C}-\mathrm{H}), 2925 \mathrm{~s}(\mathrm{C}-\mathrm{H}), 2862 \mathrm{~s}(\mathrm{C}-\mathrm{H}), 1506 \mathrm{~m}(\mathrm{C} \equiv \mathrm{N}), 1461 \mathrm{~m}, 1400 \mathrm{~m}$, 1367m, 1361m, 1283m, 1145s, 1118s, 1092s, 1051s, 1035s, 804w. Far-IR(CsI, cm $\left.{ }^{-1}\right): 685 \mathrm{w}$, 587m(C-Cl), 561w, 540w, 501,476w, 437w, 411w, 389w, 371w, 349w, 276w, 237br. Raman (solid, $\mathrm{cm}^{-1}$ ): 2974s(C-H), 2913s $(\mathrm{C}-\mathrm{H}), 2865 \mathrm{~s}(\mathrm{C}-\mathrm{H}), 1507 \mathrm{~m}(\mathrm{C} \equiv \mathrm{N}), 1495 \mathrm{~m}(\mathrm{C} \equiv \mathrm{N}), 1461 \mathrm{~m}$, $1448 \mathrm{~m}, 1430 \mathrm{~m}, 1382 \mathrm{~m}, 1369 \mathrm{~s}, 1300 \mathrm{~m}, 1283 \mathrm{~m}, 1176 \mathrm{w}, 1145 \mathrm{w}, 1107 \mathrm{~m}, 957 \mathrm{w}, 880 \mathrm{~m}, 706 \mathrm{w}$, 657m, 575m(C-Cl), 511m(Ag-N), 438w, 385w, 341w, 268m. ${ }^{1} \mathrm{H}-\mathrm{NMR}\left(\mathrm{CDCl}_{3}, 500 \mathrm{MHz}\right)$ : $\delta 1.41(\mathrm{~d}, J=7 \mathrm{~Hz}, 36 \mathrm{H}, \mathrm{CHMe}$ ), $\delta 3.13$ (sept, $J=7 \mathrm{~Hz}, 6 \mathrm{H}, \mathrm{CHMe}$ ). UV-Vis (solution, cyclohexane, $\left.\lambda_{\max } / \mathrm{nm}\left(\varepsilon / \mathrm{cm}^{-1} \mathrm{~mol}^{-1} \mathrm{dm}^{3}\right)\right) 226$ (39200). UV-Vis (solid, Nujol, $\left.\mathrm{nm}\right): 248$, 280 (sh). Emission at $280 \mathrm{~nm}$ excitation wavelength (solution, cyclohexane, $\lambda_{\max } / \mathrm{nm}$ ): 307 . Emission at $280 \mathrm{~nm}$ excitation wavelength (solid, $\lambda_{\max } / \mathrm{nm}$ ): $299 \mathrm{~K}, 315,490 ; 173 \mathrm{~K}, 314$, 474, 614sh; $83 \mathrm{~K}, 317,331,346,362,379,456 \mathrm{sh}, 473$.

Liquid-liquid diffusion was applied to obtain crystals at room temperature. The $\left\{[\mathrm{Ag}(\mu-\mathrm{L} 1 \mathrm{Clpz})]_{3}\right\}_{2}(0.05 \mathrm{mmol})$ in $10 \mathrm{~mL}$ of ethyl acetate was transferred to a $30 \mathrm{~mL} \mathrm{Er}-$ lenmeyer flask. On this solution, the solution containing $\left({ }^{\mathrm{n}} \mathrm{Bu}_{4} \mathrm{~N}\right)\left[\mathrm{Ag}(\mathrm{CN})_{2}\right](0.1 \mathrm{mmol})$ dissolved in $10 \mathrm{~mL}$ of ethyl acetate was carefully layered and then the top was covered by parafilm. After a few weeks, some crystals were formed, which were suitable for single-crystal X-ray analysis.

\subsection{X-ray Crystal Structure Determination}

Crystal data and refinement parameters for the silver(I) pyrazolato coordination polymer $[\mathbf{A g}(\mu-\mathrm{L} 1 \mathrm{Clpz})]_{n}$ are given in Table 1 . All crystallographic data have been deposited at the Cambridge crystallographic data center (CCDC), 12 Union Road, Cambridge CB2 $1 \mathrm{EZ}, \mathrm{UK}$ and copies can be obtained on request, free of charge, by quoting the publication citation and the deposition number. CCDC number: 2053891.

The diffraction data were measured on a Rigaku/MSC Mercury CCD system (Rigaku, Tokyo, Japan) with graphite monochromated Mo $K \alpha(\lambda=0.71070 \AA)$ radiation at $-80^{\circ} \mathrm{C}$. The unit cell parameters of each crystal were determined using CrystalClear [36] from 6 images. The crystal to detector distance was $44.74 \mathrm{~mm}$. Data were collected using $0.5^{\circ}$ intervals in $65 \varphi$ and $\omega$ to a maximum $2 \theta$ value of $55.0^{\circ}$. A total of 744 oscillation images were collected. The highly redundant data sets were reduced using CrysAlisPro [37]. An empirical absorption correction was applied for each complex. Structures were solved by direct methods (SIR2008) [38]. The position of the silver ions and their first coordination 
sphere were located from a direct method E-map; other non-hydrogen atoms were found in alternating difference Fourier syntheses and least squares refinement cycles. During the final refinement cycles the temperature factors were refined anisotropically. Refinement was carried out by a full matrix least-squares method on $F^{2}$. All calculations were performed with the CrystalStructure [39] crystallographic software package except for refinement, which was performed using SHELXL 2013 [40]. Hydrogen atoms were placed in calculated positions. Crystallographic data and structure refinement parameters including the final discrepancies ( $R$ and $R w$ ) are listed in Table 1.

Table 1. Crystal data and structure refinement of $[\mathrm{Ag}(\mu-\mathrm{L1Clpz})]_{n}$.

\begin{tabular}{|c|c|}
\hline Complex & {$[\operatorname{Ag}(\mu-\mathrm{L} 1 \mathrm{Clpz})]_{n}$} \\
\hline CCDC number & 2053891 \\
\hline Empirical Formula & $\mathrm{C}_{9} \mathrm{H}_{14} \mathrm{AgClN}{ }_{2}$ \\
\hline Formula Weight & 293.54 \\
\hline Crystal System & Monoclinic \\
\hline Space Group & $I 2 / a(\# 15)$ \\
\hline$a / \AA$ & $9.4667(11)$ \\
\hline$b / \AA$ & $11.0962(3)$ \\
\hline$c / \AA$ & $21.5508(7)$ \\
\hline$\beta /{ }^{\circ}$ & $94.859(2)$ \\
\hline$V / \AA^{3}$ & $2255.66(11)$ \\
\hline Z & 8 \\
\hline$D_{\text {calc }} / \mathrm{g} \mathrm{cm}^{-3}$ & 1.729 \\
\hline$\mu(\mathrm{MoK} \alpha) / \mathrm{cm}^{-1}$ & 19.771 \\
\hline Temperature $/{ }^{\circ} \mathrm{C}$ & -80 \\
\hline $2 \theta$ range $^{\circ}$ & $6-55$ \\
\hline Reflections collected & 8801 \\
\hline Unique reflections & 2589 \\
\hline$R_{\text {int }}$ & 0.0111 \\
\hline Number of Variables & 120 \\
\hline Refls./Para ratio & 21.57 \\
\hline Residuals: $R 1(I>2 \sigma(I))$ & 0.0155 \\
\hline Residuals: $R$ (All reflections) & 0.0167 \\
\hline Residuals: $w R 2$ (All reflections) & 0.0406 \\
\hline Goodness of fit indicator & 1.046 \\
\hline Max/min peak,/e $\AA^{-3}$ & $0.43 /-0.40$ \\
\hline
\end{tabular}

$R 1=\Sigma|| F_{o}|-| F_{c}|| / \Sigma\left|F_{o}\right|, w R 2=\left[\Sigma\left(w\left(F o^{2}-F c^{2}\right)^{2}\right) / \Sigma w\left(F o^{2}\right)^{2}\right]^{1 / 2}$.

\section{Conclusions}

By using an unexpected synthetic method, we obtained a silver(I) pyrazolato complex $[\mathrm{Ag}(\mu-\mathrm{L} 1 \mathrm{Clpz})]_{n}$ as a coordination polymer by the reaction of $\left\{[\mathrm{Ag}(\mu-\mathrm{L} 1 \mathrm{Clpz})]_{3}\right\}_{2}$ with $\left({ }^{\mathrm{n}} \mathrm{Bu}_{4} \mathrm{~N}\right)\left[\mathrm{Ag}(\mathrm{CN})_{2}\right]$. This polynuclear silver(I) structure was compared with the known hexanuclear silver(I) structure $\left\{[\mathrm{Ag}(\mu-\mathrm{L} 1 \mathrm{Clpz})]_{3}\right\}_{2}$. Two $\mathrm{N}-\mathrm{Ag}-\mathrm{N}$ bond angles of $180.00(7)^{\circ}$ and $179.83(5)^{\circ}$ in the silver(I) coordination polymer $[\mathbf{A g}(\mu-\mathbf{L} \mathbf{C l} \mathbf{C l p z})]_{n}$ indicate that each silver(I) ion is coordinated by two pyrazolyl nitrogen atoms with an almost linear coordination. Every five pyrazoles point in the same direction to form a 1-D zig-zag structure. This zig-zag structure is not stable in solution, but it converts to the original hexanuclear silver(I) complex $\left\{[\mathrm{Ag}(\mu-\mathrm{L} 1 \mathrm{Clpz})]_{3}\right\}_{2}$. In the solid-state photoluminescence spectrum, a lower energy strong emission band at $473 \mathrm{~nm}$ at lower temperature is very unique and attributable to the differences in polynuclear structure between the two systems. Silver(I) complexes are not generally so emissive, even at lower temperature and thus this 1-D zigzag polynuclear structure is particularly noteworthy in coinage metal(I) pyrazolate research. This [Ag( $\boldsymbol{\mu}-\mathbf{L} \mathbf{L C l p z})]_{n}$ broadens a family of silver(I) coordination polymers $[24,25,41-43]$. Moreover, some high antibacterial activity research using silver(I) coordination polymers are also reported [41-44]. Further efforts to probe how the structure of coinage metal(I) pyrazolates is affected by ligand and coordination environment are in progress. 
Supplementary Materials: The following are available online, CIF and checkCIF reportr. Figure S1: 1-D polynuclear structure of $[\mathrm{Ag}(\mu-\mathrm{pz})]_{n}$, Figure S2: Packing diagram of $[\mathrm{Ag}(\mu-\mathrm{pz})]_{n}$, Figure S3: Powder X-ray diffraction spectra of $[\mathbf{A g}(\mu-\mathbf{L} 1 \mathrm{Clpz})]_{n}$ and calcd. pattern, Figure S4: Packing diagram of $[\mathrm{Ag}(\mu-\mathrm{L1Clpz})]_{n}$, Figure S5: Crystal structure of $\left\{[\mathrm{Ag}(\mu-\mathrm{L} 1 \mathrm{Clpz})]_{3}\right\}_{2}$, Figure S6: Packing diagram of $\left\{[\mathrm{Ag}(\mu-\mathrm{L} 1 \mathrm{Clpz})]_{3}\right\}_{2}$, Figure S7: ${ }^{1} \mathrm{H}-\mathrm{NMR}$ spectrum of $[\mathbf{A g}(\mu-\mathbf{L} 1 \mathrm{Clpz})]_{n}$, Table S1: Comparisons of the ${ }^{1} \mathrm{H}-\mathrm{NMR}$ chemical shifts, Figure S8: UV-Vis spectra of $[\mathrm{Ag}(\mu-\mathrm{L} 1 \mathrm{Clpz})]_{n}$ and $\left\{[\mathrm{Ag}(\mu-\mathrm{L} 1 \mathrm{Clpz})]_{3}\right\}_{2}$ in cyclohexane, Figure S9: Luminescence spectra of $[\mathrm{Ag}(\mu-\mathrm{L1Clpz})]_{n}$ and $\left\{[\mathrm{Ag}(\mu-\mathrm{L} 1 \mathrm{Clpz})]_{3}\right\}_{2}$ in cyclohexane, Figure S10: IR spectra of $[\mathbf{A g}(\mu-\mathbf{L} 1 \mathrm{Clpz})]_{n}$ and $\left\{[\mathrm{Ag}(\mu-\mathrm{L} 1 \mathrm{Clpz})]_{3}\right\}_{2}$, Figure S11: Raman spectra of $[\mathrm{Ag}(\mu-\mathrm{L} 1 \mathrm{Clpz})]_{n}$ and $\left\{[\mathrm{Ag}(\mu-\mathrm{L} 1 \mathrm{Clpz})]_{3}\right\}_{2}$, Figure S12: Temperature-dependent photoluminescence spectra in $\left\{[\mathrm{Ag}(\mu-\mathrm{L} 1 \mathrm{Clpz})]_{3}\right\}_{2}$.

Author Contributions: K.F. and D.B.L. conceived and designed the project. T.N. and Y.M. performed the experiments. T.N. and K.F. analyzed the data. K.F. and D.B.L. wrote the paper. All authors have read and agreed to the published version of the manuscript.

Funding: This research received no directed/sponsored external funding.

Data Availability Statement: Data is contained within the article and supplementary material.

Acknowledgments: K.F. is grateful for the support from an Ibaraki University Priority Research Grant and the joint usage/research program "Artificial Photosynthesis" based at Osaka City University. DBL is grateful to NSERC of Canada for ongoing research support via the Discovery Grant program.

Conflicts of Interest: The authors declare no conflict of interest.

Sample Availability: Samples of the compounds $[\mathbf{A g}(\mu-\mathbf{L} 1 \mathrm{Clpz})]_{n}$ and $\left\{[\mathrm{Ag}(\mu-\mathrm{L} 1 \mathrm{Clpz})]_{3}\right\}_{2}$ are available from the authors.

\section{References}

1. Zheng, J.; Lu, Z.; Wu, K.; Ning, G.-H.; Li, D. Coinage-metal-based cyclic trinuclear complexes with metal-metal interactions: Theories to experiments and structures to functions. Chem. Rev. 2020, 120, 9675-9742. [CrossRef] [PubMed]

2. Zheng, J.; Yang, H.; Xie, M.; Li, D. The $\pi$-acidity/basicity of cyclic trinuclear units (CTUs): From a theoretical perspective to potential applications. Chem. Commun. 2019, 55, 7134-7146. [CrossRef] [PubMed]

3. Galassi, R.; Rawashdeh-Omary, M.A.; Dias, H.V.R.; Omary, M.A. Homoleptic cyclic trinuclear d $\mathrm{d}^{10}$ complexes: From selfassociation via metallophilic and excimeric bonding to the breakage thereof via oxidative addition, dative bonding, quadrupolar, and heterometal bonding interactions. Comments Inorg. Chem. 2019, 39, 287-348. [CrossRef]

4. Elguero, J.; Alkorta, I. A computational study of metallacycles formed by pyrazolate ligands and the coinage metals $\mathrm{M}=\mathrm{Cu}(\mathrm{I})$, $\mathrm{Ag}(\mathrm{I})$ and $\mathrm{Au}(\mathrm{I}):(\mathrm{pzM})_{n}$ for $n=2,3,4,5$ and 6. comparison with structures reported in the Cambridge crystallographic data center (CCDC). Molecules 2020, 25, 5108. [CrossRef] [PubMed]

5. Omary, M.A.; Mohamed, A.A.; Rawashdeh-Omary, M.A.; Fackler, J.P., Jr. Photophysics of supramolecular binary stacks consisting of electron-rich trinuclear $\mathrm{Au}(\mathrm{I})$ complexes and organicelectrophiles. Coord. Chem. Rev. 2005, 249, 1372-1381. [CrossRef]

6. Zhang, J.-P.; Zhang, Y.-B.; Lin, J.-B.; Chen, X.-M. Metal azolate frameworks: From crystal engineering to functional materials. Chem. Rev. 2012, 112, 1001-1033. [CrossRef]

7. Halcrow, M.A. Pyrazoles and pyrazolides-Flexible synthons in self-assembly. Dalton Trans. 2009, 2059-2073. [CrossRef]

8. Trofimenko, S. The coordination chemistry of pyrazole-derived ligands. Chem. Rev. 1972, 72, 497-509. [CrossRef]

9. Trofimenko, S. Recent advances in poly(pyrazolyl)borate (scorpionate) chemistry. Chem. Rev. 1993, 93, 943-982. [CrossRef]

10. Reimlinger, H.; Noels, A.; Jabot, J.; van Overstraeten, A. Synthesis with silver or sodium pyrazoles, I preparation of mono- and polypyrazoles. Chem. Ber. 1970, 103, 1942-1948. [CrossRef]

11. Okkersen, H.; Groeneveld, W.L.; Reedijk, J. Pyrazoles and imidazoles as ligands. Part XVIII: Neutral and anionic pyrazole coordinated to $\mathrm{Cu}(\mathrm{I})$ and Ag(I). Recl. Trav. Chim. Pays-Bas 1973, 92, 945-953. [CrossRef]

12. Murray, H.H.; Raptis, R.G.; Fackler, J.P., Jr. Syntheses and X-ray structures of group 11 pyrazole and pyrazolate complexes. X-ray crystal structures of bis(3,5-diphenylpyrazole)copper(II) dibromide, tris( $\mu$-3,5-diphenylpyrazolato- $\left.N, N^{\prime}\right)$ trisilver(I)-2tetrahydrofuran, tris $\left(\mu-3,5\right.$-diphenylpyrazolato- $\left.N, N^{\prime}\right)$ trigold(I), and hexakis $\left(\mu-3,5\right.$-diphenylpyrazolato- $\left.N, N^{\prime}\right)$ hexagold(I). Inorg. Chem. 1988, 27, 26-33.

13. Mohamed, A.A.; Pérez, L.M.; Fackler, J.P. Jr. Unsupported intermolecular argentophilic interaction in the dimer of trinuclear silver(I) 3,5-diphenylpyrazolates. Inorg. Chim. Acta 2005, 358, 1657-1662. [CrossRef]

14. Schmidbaur, H.; Schier, A. Argentophilic interactions. Angew. Chem. Int. Ed. 2015, 54, 746-784. [CrossRef] [PubMed]

15. Masciocchi, N.; Moret, M.; Cairati, P.; Sironi, A.; Ardizzoia, G.A.; Monica, G.L. The multiphase nature of the Cu(pz) and Ag(pz) $(\mathrm{Hpz}=$ pyrazole $)$ systems: Selective syntheses and ab-initio X-ray powder diffraction structural characterization of copper(I) and silver(I) pyrazolates. J. Am. Chem. Soc. 1994, 116, 7668-7676. [CrossRef] 
16. Zhang, C.-Y.; Feng, J.-B.; Gao, Q.; Xie, Y.-B. catena-Poly[silver(I)- $\mu$-pyrazolato- $\left.\kappa^{2} N: N^{\prime}\right]$. Acta Cryst. 2008, 64, m352. [CrossRef] [PubMed]

17. Fujisawa, K.; Okano, M.; Martín-Pastor, M.; López-Sánchez, R.; Elguero, J.; Alkorta, I. Multinuclear magnetic resonance studies of five silver(I) trinuclear pyrazolate complexes. Struct. Chem. 2021, 32, 215-224. [CrossRef]

18. Fujisawa, K.; Saotome, M.; Takeda, S.; Young, D.J. Structures and photoluminescence of coinage metal(I) phenylpyrazolato trinuclear complexes $\left[\mathrm{M}\left(3,5-\mathrm{Et}_{2}-4-\mathrm{Ph}-\mathrm{pz}\right)\right]_{3}$ and arene sandwich complexes $\left\{\left[\mathrm{Ag}\left(3,5-\mathrm{Et}_{2}-4-\mathrm{Ph}-\mathrm{pz}\right)\right]_{3}\right\}_{2}(\mathrm{Ar})(\mathrm{Ar}=\mathrm{mesitylene}$ and toluene). Chem. Lett. 2020, 49, 670-673. [CrossRef]

19. Saotome, M.; Shimizu, D.; Itagaki, A.; Young, D.J.; Fujisawa, K. Structures and photoluminescence of silver(I) and gold(I) cyclic trinuclear complexes with aryl substituted pyrazolates. Chem. Lett. 2019, 48, 533-536. [CrossRef]

20. Morishima, Y.; Young, D.J.; Fujisawa, K. Structure and photoluminescence of silver(I) trinuclear halopyrazolato complexes. Dalton Trans. 2014, 43, 15915-15928. [PubMed]

21. Fujisawa, K.; Ishikawa, Y.; Miyashita, Y.; Okamoto, K. Pyrazolate-bridged group 11 metal(I) complexes: Substituent effects on the supramolecular structures and physicochemical properties. Inorg. Chim. Acta 2010, 363, 2977-2989. [CrossRef]

22. Fujisawa, K.; Ishikawa, Y.; Miyashita, Y.; Okamoto, K. Crystal structure of pyrazolato-bridged copper(I) polynuclear complexes. Chem. Lett. 2004, 33, 66-67. [CrossRef]

23. Burini, A.; Bravi, R.; Fackler, J.P., Jr.; Galassi, R.; Grant, T.A.; Omary, M.A.; Pietroni, B.R.; Staples, R.J. Luminescent chains formed from neutral, triangular gold complexes sandwiching $\mathrm{Tl}^{\mathrm{I}}$ and $\mathrm{Ag}$. structures of $\left\{\mathrm{Ag}\left(\left[\mathrm{Au}\left(\mu-\mathrm{C}^{2}, \mathrm{~N}^{3}-\mathrm{bzzim}_{3}\right]_{3}\right)_{2}\right\} \mathrm{BF}_{4} \cdot \mathrm{CH}_{2} \mathrm{Cl}_{2}\right.$, $\left\{\mathrm{Tl}\left(\left[\mathrm{Au}\left(\mu-\mathrm{C}^{2}, \mathrm{~N}^{3}-\mathrm{bzim}\right)\right]_{3}\right)_{2}\right\} \mathrm{PF}_{6} \cdot 0.5 \mathrm{THF}(\mathrm{bzim}=1$-Benzylimidazolate $)$, and $\left\{\mathrm{Tl}\left(\left[\mathrm{Au}\left(\mu-\mathrm{C}(\mathrm{OEt})=\mathrm{NC}_{6} \mathrm{H}_{4} \mathrm{CH}_{3}\right)\right]_{3}\right)_{2}\right\} \mathrm{PF}_{6} \cdot \mathrm{THF}$, with $\mathrm{MAu}_{6}\left(\mathrm{M}=\mathrm{Ag}^{+}, \mathrm{Tl}^{+}\right)$cluster cores. Inorg. Chem. 2000, 39, 3158-3165.

24. Baril-Robert, F.; Li, X.; Katz, M.J.; Geisheimer, A.R.; Leznoff, D.B.; Patterson, H. Changes in electronic properties of polymeric one-dimensional $\left\{\left[\mathrm{M}(\mathrm{CN})_{2}\right]^{-}\right\}_{n}(\mathrm{M}=\mathrm{Au}, \mathrm{Ag})$ chains due to neighboring closed-shell $\mathrm{Zn}(\mathrm{II})$ or open-shell Cu(II) ions. Inorg. Chem. 2011, 50, 231-237. [CrossRef] [PubMed]

25. Shorrock, C.J.; Xue, B.-Y.; Kim, P.B.; Batchelor, R.J.; Patrick, B.O.; Leznoff, D.B. Heterobimetallic coordination polymers incorporating $\left[\mathrm{M}(\mathrm{CN})_{2}\right]^{-}(\mathrm{M}=\mathrm{Cu}, \mathrm{Ag})$ and $\left[\mathrm{Ag}_{2}(\mathrm{CN})_{3}\right]^{-}$units: Increasing structural dimensionality via $\mathrm{M}-\mathrm{M}^{\prime}$ and $\mathrm{M} \cdots \mathrm{NC}$ interactions. Inorg. Chem. 2002, 41, 6743-6753. [CrossRef]

26. Rawashdeh-Omary, M.A.; Omary, M.A.; Patterson, H.H.; Fackler, J.P., Jr. Excited-state interactions for $\left[\mathrm{Au}(\mathrm{CN})_{2}{ }^{-}\right]_{n}$ and $\left[\mathrm{Ag}(\mathrm{CN})_{2}{ }^{-}\right]_{n}$ oligomers in solution. Formation of luminescent gold-gold bonded excimers and exciplexes. J. Am. Chem. Soc. 2001, 123, 11237-11247. [CrossRef]

27. Omary, M.A.; Webb, T.R.; Assefa, Z.; Shankle, G.E.; Patterson, H.H. Crystal structure, electronic structure, and temperaturedependent Raman spectra of $\mathrm{Tl}\left[\mathrm{Ag}(\mathrm{CN})_{2}\right]$ : Evidence for ligand-unsupported argentophilic interactions. Inorg. Chem. 1998, 37, 1380-1386. [CrossRef]

28. Omary, M.A.; Patterson, H.H. Temperature-dependent photoluminescence properties of $\mathrm{Tl}\left[\mathrm{Ag}(\mathrm{CN})_{2}\right]$ : Formation of luminescent metal-metal-bonded inorganic exciplexes in the solid state. Inorg. Chem. 1998, 37, 1060-1066. [CrossRef]

29. Dragulescu-Andrasi, A.; Hietsoi, O.; Üngör, Ö.; Dunk, P.W.; Stubbs, V.; Arroyave, A.; Kovnir, K.; Shatruk, M. Dicyanometalates as building blocks for multinuclear iron(II) spin-crossover complexes. Inorg. Chem. 2019, 58, 11920-11926. [CrossRef]

30. Bondi, A. van der Waals volume and radii. J. Phys. Chem. 1964, 68, 441-451. [CrossRef]

31. Nakamoto, K. Infrared and Raman spectra of inorganic and coordination compounds, 6th ed.; John Wiley and Sons, Inc.: New York, NY, USA, 2009.

32. Omary, M.A.; Rawashdeh-Omary, M.A.; Gonser, M.W.A.; Elbjeirami, O.; Grimes, T.; Cundari, T.R.; Diyabalanage, H.V.K.; Gamage, C.S.P.; Dias, H.V.R. Metal Effect on the supramolecular structure, photophysics, and acid-base character of trinuclear pyrazolato coinage metal complexes. Inorg. Chem. 2005, 44, 8200-8210. [CrossRef] [PubMed]

33. Grimes, T.; Omary, M.A.; Dias, H.V.R.; Cundari, T.R. Intertrimer and intratrimer metallophilic and excimeric bonding in the ground and phosphorescent states of trinuclear coinage metal pyrazolates: A computational study. J. Phys. Chem. A 2006, 110, 5823-5830. [CrossRef] [PubMed]

34. Hettiarachchi, C.V.; Rawashdeh-Omary, M.A.; Korir, D.; Kohistani, J.; Yousufuddin, M.; Dias, H.V.R. Trinuclear copper(I) and silver(I) adducts of 4-chloro-3,5-bis(trifluoromethyl)pyrazolate and 4-bromo-3,5-bis(trifluoromethyl)pyrazolate. Inorg. Chem. 2013, 52, 13576-13583. [CrossRef]

35. Kitajima, N.; Fujisawa, K.; Fujimoto, C.; Moro-oka, Y.; Hashimoto, S.; Kitagawa, T.; Toriumi, T.; Tatsumi, K.; Nakamura, A. A new model for dioxygen binding in hemocyanin. Synthesis, characterization, and molecular structure of the $\mu-\eta^{2}: \eta^{2}$ peroxo dinuclear copper(II) complexes, $\left[\mathrm{Cu}\left(\mathrm{HB}\left(3,5-\mathrm{R}_{2} \mathrm{pz}\right)_{3}\right)\right]_{2}\left(\mathrm{O}_{2}\right)(\mathrm{R}=i$-Pr and $\mathrm{Ph})$. J. Am. Chem. Soc. 1992, 114, 1277-1291. [CrossRef]

36. CrystalClear: Data Collection and Processing Software; Rigaku Corporation: Tokyo, Akishima, Japan, 1999.

37. Crys AlisPro: Data Collection and Processing Software; Rigaku Corporation: Tokyo, Akishima, Japan, 2015.

38. Burla, M.C.; Caliandro, R.; Camalli, M.; Carrozzini, B.; Cascarano, G.L.; De Caro, L.; Giacovazzo, C.; Polidori, G.; Siliqi, D.; Spagna, R. IL MILIONE: A suite of computer programs for crystal structure solution of proteins. J. Appl. Cryst. 2007, 40, 609-613. [CrossRef]

39. Crystal Structure 4.3: Crystal Structure Analysis Package; Rigaku Corporation: Tokyo, Akishima, Japan, 2019.

40. Sheldrick, G.M. A short history of SHELX. Acta Cryst. 2008, A64, 112-122. [CrossRef]

41. Jaros, S.W.; da Silva, M.F.C.G.; Florek, M.; Smoleński, P.; Pombeiro, A.J.L.; Kirillov, A.M. Silver(I) 1,3,5-triaza-7-phosphaadamantane coordination polymers driven by substituted glutarate and malonate building blocks: Self-assembly synthesis, structural features, and antimicrobial properties. Inorg. Chem. 2016, 55, 5886-5894. [CrossRef] 
42. Lu, X.; Ye, J.; Zhang, D.; Xie, R.; Bogale, R.F.; Sun, Y.; Zhao, L.; Zhao, Q.; Ning, G. Silver carboxylate metal-organic frameworks with highly antibacterial activity and biocompatibility. J. Inorg. Biochem. 2014, 138, 114-121. [CrossRef] [PubMed]

43. Jaros, S.W.; Smoleński, P.; da Silva, M.F.C.G.; Florek, M.; Król, J.; Staroniewicz, Z.; Pombeiro, A.J.L.; Kirillov, A.M. New silver BioMOFs driven by 1,3,5-triaza-7-phosphaadamantane-7-sulfide (PTA=S): Synthesis, topological analysis and antimicrobial activity. CrystEngComm 2013, 15, 8060-8064. [CrossRef]

44. Domb, A.J.; Kunduru, K.R.; Farah, S. Antimicrobial Materials for Biomedical Applications; The Royal Society of Chemistry: Croydon, UK, 2019. 